p. 150

体青学研究 $\mathrm{X}-1$

而的文化と人形成

東京教育大学附属高校○中村雄，鈴木善雄

$\begin{array}{ll}\text { 東京教育大学 } & \text { 丹 保夫 } \\ \text { 和 光学園 } & \text { 吉 绮高弘 }\end{array}$

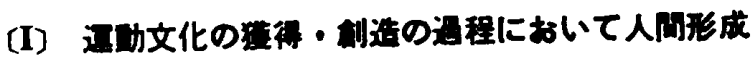
は行なわれる

（1）運動交化を得得・創造していく過程において人間 形成が実現されるといらことは，いつの時代です，また どのよらな社会においてもよく知られており，実践され ていた。

（2）運動文化を蒦得・創造していく遗程で実现される 人閏形成は，大別して，身体的・技術的側面と，精神 的・思想的側面との二側面から把提することがでをる。

(3) 身体的・接術的側面に打ける人間形成怊民的 性格の強いものであり，精神的・思想的㑡面における人 間形成は，とくに倫理的・道徳的側面においては，かな り超民族的等質性をむちながらす，多分に民族的・陼股 的性格の強いあのである.

(II) 正勑文化の近代化とは何か

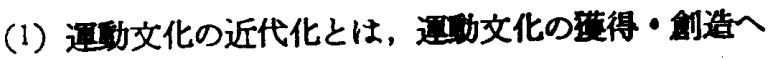
のより多くの近代市民二ブルシショワジーの加，広い地 域にわたるルールの統一，組唃的な競技会の企画や運 営，技術練習の体系化の確立などを意味し，それが近代 合理主義に支えられたすのであつたといえよ5。

（2）しかし，運動交化近代化のにない手が，近代市民 階級であつたといらことから，自らそこに限界のあつた ことあ止むを得ないことであつた。

(3) 運動文化の近代化は，㮩本主美社会成立のイニシ アテイブをるつた英国で，19世紀の中期以降にまず行 なわれた。

(III) 19世紀後半の英国社会における人问形成睘求 と可娌文化

(1) ブルシショワジーの自由な自己保在活動=営利活動 が，そのまま市民社会の秩序であるといらことが認めら

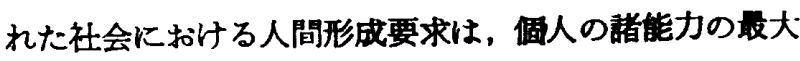
限の開花を期特するものであり，高島氏らによれば，そ れは「個人の利已心と社会の秩序との統一が慜策件に一 致し得る人々」のことであり，そのよらな人^とは，独 立生産者から産業资本家へと上年しつつある人々のこと であつた。

（2）クローハルな見力をすれば，近代英国社会におけ る人間形成要求と，近代化されつつあつた運動文化の蕰
得・創造の過程で達成される人間形成とは，はほ満足に 一政したあのであつたと考えることができる。

(IV) 而助文化の近代化遗程において内藏された人 问磷外的条件とは何か

(1) 近代化の過程において次第に全世界的なるのにな つた運文化を、より科学の発展した現代といら時点に 立つて䁖める時，そこには现代に生きる人民大采の享受 乙得ない人間䠅外的条件の内藏が指摘され得る. 吉崎, 鈴木两氏の述べるところがそれである.

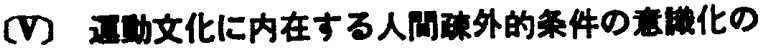
其要性

（1）運怔文化を篹得・創造していく過程の中に潜在的 に，或は夏在化している人間疎外的条件を明確に意裁与 ることは極めて重要である。

（2）ではこれまで，運動文化を得得・創造していくと い5目的的活動の中で蹯外されていたものは誰か. それ は，通常運称神释のにぶいといわれているすのであり，

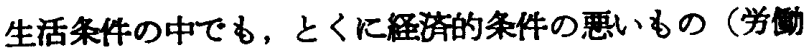
者階伋)であり，封建的生活諸条件の中に最かれたるの であつた。

（3）現代社会に括ける体育科教育は，このような課題

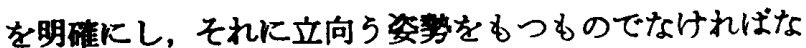
らない。

\section{[VI] 可的文化改革の裸点}

(1)この間题へのアプローチとして，第一に，現代社 会における人間形成要求とは何か，といらことが先つ問 われなければならないだろら．弱台氏は，「全体的人間」 といらことばでこれをあらわしている。

（2）このような人間形成を目的として行なわれる体育 科数育においては，最初に述へた身体的・接術的側面， およひ棈神的・思想的側面に関保する諸科学の成果を活 用して，指導の内容や方法の科学化が実現されねばなら ない。

（3）これを，身体的・技術的側面について述べるなら ば，技術の向上，体力の增強のための内容と方法とを， 人間自身の側にたつて科学的に明確にしていくことであ ク，精神的・思想的㑡面について述べるならば，何より む，五功文化に内荿されている階級性を払拭し，あわせ て，運洏文化をとりまく外㑡の体制や組縟の民主化を

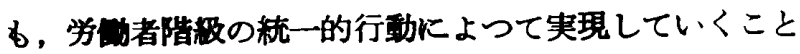
であろらと考えられる。 